\title{
Civil war: is it all about disease and xenophobia? A comment on Letendre, Fincher \& Thornhill
}

\author{
Cullen S. Hendrix \\ William \& Mary \\ Kristian Skrede Gleditsch \\ Kristian Skrede Gleditsch
}

Follow this and additional works at: https://scholarworks.wm.edu/aspubs

\section{Recommended Citation}

Hendrix, C. S., \& Gleditsch, K. S. (2012). Civil war: Is it all about disease and xenophobia? A comment on Letendre, Fincher \& Thornhill. Biological Reviews, 87(1), 163-167.

This Article is brought to you for free and open access by the Arts and Sciences at W\&M ScholarWorks. It has been accepted for inclusion in Arts \& Sciences Articles by an authorized administrator of W\&M ScholarWorks. For more information, please contact scholarworks@wm.edu. 


\title{
Givil war: is it all about disease and xenophobia? A comment on Letendre, Fincher \& Thornhill
}

\author{
Cullen S. Hendrix ${ }^{1, *}$ and Kristian Skrede Gleditsch ${ }^{2,3}$ \\ ${ }^{1}$ Department of Government, The College of William and Mary, P.O. Box 8795 Williamsburg, VA 23187-8795, USA \\ ${ }^{2}$ Department of Government, University of Essex, Wivenhoe Park, Colchester C04 3SQ UK (E-mail: ksg@essex.ac.uk) \\ ${ }^{3}$ Centre for the Study of Civil War, Peace Research Institute Oslo (PRIO), PO Box 9229 Gronland NO-0134 Oslo, Norway
}

\begin{abstract}
Letendre, Fincher \& Thornhill (2010) argue that pathogen intensity provides the ultimate explanation for why some countries are more prone to civil war than others. They argue that the economic and political factors highlighted in previous research on civil war are largely caused by underlying differences in pathogen intensity, and contend that disease proneness increases the risk of civil war through its effects on resource competition and xenophobia. They present empirical evidence that they interpret as consistent with their argument: a statistically significant correlation between pathogen intensity and civil war onset. In this comment, we raise concerns over their interpretation of the empirical evidence and their proposed causal mechanisms. We find that the data provide stronger evidence for the reverse causal relationship, namely that civil war causes disease to become more prevalent. This finding is consistent with the literatures on the public health effects of civil war as well as research on state capacity and public health.
\end{abstract}

Key words: civil war, collectivism-individualism, infectious disease, intrastate armed conflict, national wealth, pathogens, parasite.

\section{GONTENTS}

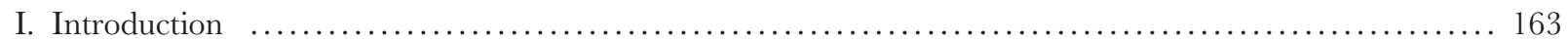

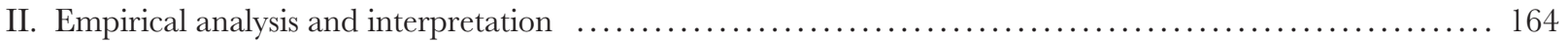

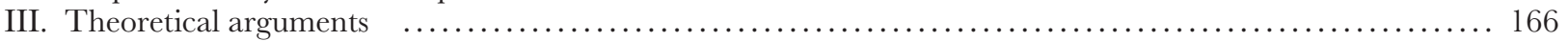

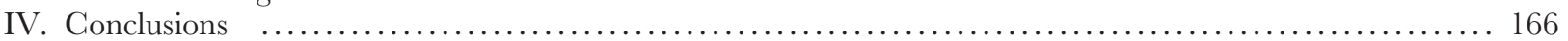

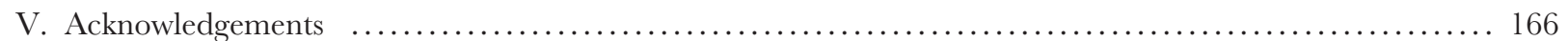

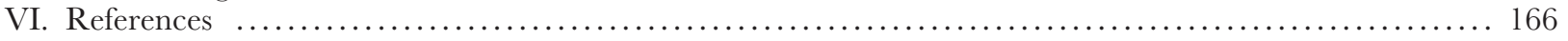

\section{INTRODUCTION}

In a recent study published in Biological Reviewes, Letendre, Fincher \& Thornhill (2010, henceforth LFT) argue that pathogen intensity provides the ultimate explanation for why some countries are more prone to civil war than others. They argue that the economic and political factors identified in previous research on civil war are largely caused by underlying differences in pathogen intensity, and contend that disease proneness increases the risk of civil war through its effects on resource competition and xenophobia. They present empirical evidence that they interpret as consistent with their argument. In this comment, we raise concerns over their interpretation of the empirical evidence as well as their proposed causal mechanisms. Empirically, we present evidence that the causal arrow likely runs in the opposite direction of what LFT propose: civil conflict may cause disease to spread. Theoretically, we argue that LFT miss the central roles that the state plays both in civil war and providing better public health outcomes. Although LFT deserve credit for highlighting possible linkages between disease and conflict, we believe

* Address for correspondence: (E-mail: chendrix@wm.edu). 
that their theoretical argument is questionable and their empirical analysis is not sufficiently robust to support their conclusions.

\section{EMPIRICAL ANALYSIS AND INTERPRETATION}

LFT test the effect of pathogen intensity on civil conflict in two ways. First, they estimate time-series cross-sectional logistic regressions with the country-year as the unit of analysis for the period 1946-2004. They then collapse the time series information into a single observation per country and run a cross-sectional logistic regression.

We believe that the empirical estimates presented by LFT are problematic because they use pathogenic severity measured in 2007 to account for conflict over the period 1946-2004. As LFT note, regression analysis with countryyears as observations is a standard approach in the political science and economics literatures on intrastate conflict, although we note that unlike the studies they cite, LFT do not have longitudinal information on their main variable of interest - pathogen severity - nor do they consider autoregressive controls, which are important as civil war often recurs and some of the current covariates could reflect the impact of previous conflict (see Collier \& Hoeffler, 2004; Fearon \& Laitin, 2003; Hegre \& Sambanis, 2006).

LFT's measure of pathogen intensity, the Contemporary Pathogen Severity Index (Fincher et al., 2008) is a composite index indicating prevalence of diseases resulting from 22 parasites from seven groups. Fincher et al. (2008) collected data on the prevalence of these diseases between April and August of 2007. Our concern is not with the quality of the data per se, but that this measure of pathogen intensity is used to test a causal argument about the effect of pathogen intensity on civil conflicts that occurred between 1946 and 2004 - a period prior to the collection of the pathogen severity data.

Static, time-invariant variables in dynamic analysis can provide evidence of a causal relationship only when there is either no potential for simultaneity or when the static observation is clearly prior to period of interest. For instance, the relationship between mountainous terrain and civil conflict (Fearon \& Laitin, 2003; Hegre \& Sambanis, 2006) may be interpreted causally because there is virtually no potential for conflict to alter the physical terrain in any meaningful way. Alternately, the effect of colonial institutions on subsequent civil conflict (Blanton, Mason \& Athow, 2001; Djankov \& Reynal-Querol, 2007) could be interpreted causally because colonial institutions predated the observed civil wars, in some cases by over a century.

In the case of disease and civil war, however, we need to consider the potential for reverse causality, namely that high pathogen severity may be an outcome of conflict, or features associated with conflict, rather than a prior cause. The public health literature provides substantial evidence that disease can be promoted by civil conflict. Raoult et al. (1998) document how the largest outbreak of epidemic typhus since World War II occurred in Burundi among refugees that had been displaced by civil wars in Burundi, neighbouring Rwanda, and the Democratic Republic of Congo. The authors note that louse infestations - and the pathogens borne by them - are a major health threat in war-torn regions around the world. At a more general level, several studies have documented the detrimental public health effects of civil conflict (Ghobarah, Huth \& Russet, 2003; Li \& Wen, 2005; Plümper \& Neumayer, 2006). Civil conflicts tend to displace populations, forcing large numbers of people to live in conditions often lacking in basic sanitation and access to clean drinking water. These are precisely the conditions under which pathogen vectors, such as mosquitoes and body and head lice, tend to flourish.

Thus, LFT may well have the causal arrow reversed: conflict and pathogen severity correlate because conflict has negative effects on the living conditions of persons in conflict zones and diminishes both state and societal capacity to address public health problems. Controlling for pathogen severity prior to the outbreak of conflict, we would expect that conflict prevalence would be positively associated with disease prevalence observed post-conflict. Or alternatively, we could have a spurious relationship, as other factors associated with a higher risk of civil war, such as weak states, poor governance and discriminatory government policies, also may be associated with higher incidence of disease. We note that LFT's results could be seen as consistent with this, as the Pathogen Severity Index in many of their regressions is not significant once they control for gross domestic product (GDP) per capita, which the authors oddly interpret as evidence that GDP per capita must be determined by pathogen severity.

Ideally, one should test the possibility of reverse causality using Contemporary Pathogen Severity Index values collected prior to the window of observation. Unfortunately, such data do not appear to exist at the present. Instead, we use a proxy for pathogen severity, the percentage of 1995 population living in areas of malaria transmission in 1946, to approximate pathogen severity prior to the observation of conflict, using data from Gallup, Sachs \& Mellinger (1999). The two variables (2007 pathogen severity and 1946 population in areas of malaria transmission) are positively and relatively highly correlated $(\mathrm{r}=0.57, \mathrm{p}=0.00)$ for the relevant sample of countries. We then estimate the effect of conflict prevalence, the log of a count variable of the years of civil conflict experienced by a country from 1947 to 2006, on pathogen severity in 2007, controlling for pathogen severity prior to the window of observation. This (logged) count variable ranges from zero to 4.07 , and is a better measure of conflict prevalence than the dummy coding used as an outcome indicator in LFT's analysis. For example, a dummy coding would classify Kenya (with a single year of civil conflict) and Myanmar (with 59 years of civil conflict) as similarly conflict-affected. Moreover, the data have been extended by two years in order to cover the full period between the observations of disease prevalence. Like LFT, we use conflict data from Strand's (2006) update of the 
Uppsala/PRIO Armed Conflict dataset (Gleditsch et al., 2002). We estimate the following model using ordinary least squares regression for country $i$ :

$$
\begin{aligned}
& \text { Pathogen Severity }_{\mathrm{i}, 2007}=\alpha+\beta\left(\log \text { Conflict Prevalence }_{\mathrm{i}}\right) \\
& +\beta\left(\text { Pathogen Severity }_{\mathrm{i}, 1946}\right)+\beta\left(\log \text { Population }_{\mathrm{i}}\right) \\
& +\beta\left(\log \text { GDP per capita } a_{i}\right)+\beta(\text { GDP Growth }{ }) \\
& +\beta\left(\text { Democracy }_{\mathrm{i}}\right)+\beta\left(\text { Political Instability }_{\mathrm{i}}\right)+\varepsilon_{\mathrm{i}},
\end{aligned}
$$

where $\alpha$ is the constant term, $\beta$ is the estimated regression coefficient for the respective variables, and $\varepsilon_{\mathrm{i}}$ is the error term.

Table 1 presents the results of two models. Model 1 is a reduced form model including only (log) conflict prevalence 1947-2006, pathogen severity in 1946, and a constant term. Model 2 includes the controls found in LFT's cross-sectional estimates of conflict onset. All control variables were taken from replication data provided by LFT. The results indicate two key findings. First, past pathogen severity is strongly correlated with current pathogen severity, suggesting that there are factors unrelated to conflict, economic development, and political democracy that may account for the persistence of pathogen severity over more than sixty years. These factors are likely environmental: many pathogens, including malaria, are more prevalent in tropical and subtropical climates and at low altitudes (Sachs, Mellinger \& Gallup, 2001). Second, there is a positive relationship between conflict prevalence and pathogen severity in 2007, controlling for pathogen severity prior to conflict. Using the reduced form estimates (Model 1), moving from five years of conflict to 18 years of conflict (a one standard deviation increase) is associated with an increase in pathogen severity in 2007 of roughly one-third a standard deviation, or 1.9 points. Hence, the research design LFT implement to test the relationship between pathogen severity and civil conflict cannot substantiate a causal argument. Disease prevalence is clearly in part an outcome of conflict, and a correlation between conflict during 1946-2004 and pathogen severity in 2007 cannot be taken as conclusive evidence that the latter causes the former. Since conflict is a relatively rare event and the historical disease prevalence data are only available at odd intervals, investigating this relationship with shorter time windows is less practical. However, restricting the analysis to the last twenty years, we found results that are consistent with those presented here (coefficient estimate on conflict incidence $=0.290$, $\mathrm{p}=0.025)$.

The coefficient on $(\log )$ mean GDP per capita is negative and highly significant in Model 2. This supports the notion of an endogenous relationship between development and pathogen severity: less disease-prevalent environments tend to see higher levels of development, and higher levels of development endow societies with greater resources to invest in eradication of disease (Acemoglu, Johnson \& Robinson, 2001, Price-Smith, 2002; Pritchett \& Summers, 1996). However, the relationship is not deterministic. Countries located in initially unfavorable environments, such as
Table 1. Correlations between pathogen severity in 2007 (controlling for pathogen severity prior to conflict), and variables relevant to the onset of conflict. The results of two models are shown: (1) a reduced-form model, (2) a full model including the control variables used in Letendre et al.'s (2010) crosssectional estimates of conflict onset. Pathogen severity in 2007 was calculated using the equation given in the text

Pathogen Severity and Civil Conflict Prevalence, 1947-2006

\begin{tabular}{lcc}
\hline & $\begin{array}{c}(1) \\
\text { Pathogen } \\
\text { severity, } \\
\text { Variables }\end{array}$ & $\begin{array}{c}(2) \\
\text { Pathogen } \\
\text { severity, } \\
2007\end{array}$ \\
\hline Log conflict prevalence, 1947-2006 & $0.219^{* * *}$ & $0.112^{* *}$ \\
Pathogen severity, 1946 & $(0.051)$ & $(0.053)$ \\
& $1.087^{* * *}$ & $0.592^{* * *}$ \\
Log mean population, 1946-2004 & $(0.167)$ & $(0.182)$ \\
Log mean GDP per capita, 1946-2004 & & 0.015 \\
& & $(0.046)$ \\
Mean democracy, 1946-2004 & & $-0.401^{* * *}$ \\
Mean instability, 1946-2004 & & $-0.089)$ \\
& & $(0.011)$ \\
Mean GDP growth, 1946-2004 & & -0.021 \\
& & $(0.466)$ \\
Constant & & 0.012 \\
& & $(0.019)$ \\
Observations & & -0.012 \\
$\mathrm{R}^{2}$ & $(0.129)$ & $(0.431)$ \\
\hline \hline
\end{tabular}

${ }^{*} \mathrm{p}<0.10,{ }^{* *} \mathrm{p}<0.05,{ }^{* * *} \mathrm{p}<0.001$.

Singapore, have managed to overcome the challenges and achieve high overall public health. We also note that many efforts to eradicate disease have had explicitly political motivations. For example, efforts to eradicate malaria through draining the marshes in Southern Europe after World War II were clearly in part aimed at containing support for Communist parties (see Tognotti, 2009). The negative coefficient for a country's level of democracy in Model 2 further suggests that better governance can foster efforts to eradicate disease, as we would expect if democracies have greater incentives to invest in public health (Lake \& Baum, 2001; Gizelis, 2009).

Our analysis here considers the potential for reverse causality between conflict and disease within the full time period examined by LFT. Our results provide strong preliminary evidence that a country's past civil conflict experience can account for some of the variation in current pathogen severity and casts doubt upon the arguments of LFT. However, our analysis remains relatively crude, and there are many possible ways to improve the estimates of the causal effects of civil conflict on disease severity through more disaggregated research (see Cederman \& Gleditsch, 2009). For example, disease severity is likely to be influenced by the magnitude of the conflict, both in terms of the number of people involved as well as its geographical scope (see Buhaug \& Lujala, 2005; 
Lacina, 2006). Furthermore, more recent conflicts should be expected to have a larger impact on disease severity than more distant conflict experiences, and the impact of civil conflict on populations might also depend on other differences, such as population growth and state capacity (see Turchin \& Nefedov, 2009). The paucity of comparable longitudinal data on disease severity - the pathogen severity index is only available for 2007 and the malaria prevalence data are only available for a limited number of time points - makes it difficult to examine the linkages between civil conflict experiences and the impact on disease across countries in greater detail. However, future research may use more detailed data for individual countries to examine the specific mechanisms whereby conflict experiences influence disease, as well as the effectiveness of state countermeasures in promoting public health.

\section{THEORETIGAL ARGUMENTS}

In their article, LFT make a strong claim that pathogen severity is the ultimate cause of civil conflict, and the authors highlight the effects of disease on exacerbating resource competition and xenophobia between ethnic groups. We are skeptical of their proposed mechanism, and we believe that their argument is inconsistent with other evidence from research on civil war. Existing research does not indicate any clear or robust relationships between resource scarcity and civil war (see de Soysa \& Neumayer, 2007) or greater ethnic fragmentation and civil war (e.g., Fearon \& Laitin, 2003). More generally, LFT seem to equate civil war with intergroup conflict and ignore the key role of the state as an actor in civil wars, which are explicitly defined as conflicts between the government of a state and a non-state actor in the Uppsala/PRIO data (Gleditsch et al., 2002, p. 619). Existing research strongly suggests that ethnic differences are only relevant for civil war insofar as states actively discriminate and exclude ethnic groups, or when there are large economic inequalities between groups (see Cederman \& Girardin, 2007; Cederman, Weidmann \& Gleditsch, 2011; Buhaug, Cederman \& Rød, 2008). Moreover, violent conflict is much more likely to arise over the distribution of rents from natural resources rather than resource scarcity per se (see Ross, 2004).

In our view, a more plausible and fruitful interpretation of the relationship between disease and conflict is that higher incidence of disease reflects important aspects of poor governance and public goods provision by the state, and that the same shortcomings that lead states to perform poorly in public health also generate grievances and opportunities that make countries more susceptible to violent mobilization. LFT deserve credit for highlighting possible and potentially interesting linkages between disease and conflict. However, just as we believe that it is premature to exclude the potential for reverse causality from conflict to disease, it seems unfortunate to resort to relatively superficial biological analogies and disregard the political motivations and strategic elements determining why groups take up violence against the state.

\section{CONCLUSIONS}

(1) LFT test the effect of pathogen intensity in 2007 on civil conflicts that occurred between 1946 and 2004, i.e., a period prior to the measurement of pathogen severity. Their analysis is thus inadequate to assess the causal effect of disease on civil conflict onset and does not take into account the potential for reverse causality or that disease prevalence may reflect prior conflict, as suggested by many prior studies.

(2) Our empirical analysis indicates pathogen severity in 2007 is positively related to prior conflict prevalence during 1947-2006, thus supporting our claim that civil conflict can have important detrimental effects for public health and disease.

(3) LFT argue that disease increases the risk of civil war through its effects on resource scarcity and xenophobia. We are skeptical of their proposed explanation, and existing research on civil war does not support the assertion that resource scarcity or ethnic fragmentation per se increase the likelihood of civil war. LFT disregard the role of the state as an active agent in civil war. Existing research indicates that ethnicity is relevant to civil war only when the state actively excludes or discriminates against certain groups, and that resource distribution is more important for conflict than resource scarcity.

(4) A more plausible and interesting interpretation of the relationship between disease and civil conflict is that higher incidence of disease reflects important aspects of poor governance and public goods provision by the state, and the same shortcomings that lead states to perform poorly in public health also generate grievances and opportunities making countries more susceptible to violent mobilization. This is consistent with our empirical analysis, which indicates that governance can influence disease prevalence, as more democratic countries have lower pathogenic severities.

\section{AGKNOWLEDGEMENTS}

We thank William Foster and two anonymous reviewers for comments on earlier iterations of this manuscript, as well as Kenneth Letendre, Corey L. Fincher, and Randy Thornhill for providing their replication data.

\section{REFERENCES}

Acemoglu, D., Johnson, S. \& Robinson, J. A. (2001). The colonial origins of comparative development: an empirical investigation. American Economic Review 91(5), $1369-1401$.

Blanton, R., Mason, T. D. \& Athow, B. (2001). Colonial style and post-colonial ethnic conflict. Fournal of Peace Research 38(4), 473-491. 
Buhaug, H., Cederman, L. E. \& RøD, J. T. (2008). Disaggregating ethno-nationalist civil wars: A dyadic test of exclusion theory. International Organization 62(3), 531-551. Buhaug, H. \& Lujala, P. (2005). Accounting for scale: Measuring geography in quantitative studies of civil war. Political Geography 24(4), 399-418.

Cederman, L. E. \& Gleditsch, K. (2009). Introduction to special issue on disaggregating the study of civil war. Fournal of Conflict Resolution 53(4), 487-495.

Cederman, L. E. \& Girardin, L. (2007). Beyond fractionalization: Mapping ethnicity onto nationalist insurgencies. American Political Science Review 101(1), $173-185$.

Cederman, L. E., Weidmann, N. B. \& Gleditsch, K. S. (2011). Horizontal inequalities and ethno-nationalist civil war: A global comparison. American Political Science Review 105(2), forthcoming.

Collier, P. \& Hoeffler, A. (2004). Greed and grievance in civil war. Oxford Economic Papers 56(4), 563-595.

DE Soysa, I. \& Neumayer, E. (2007). Resource wealth and the risk of civil war onset: Results from a new dataset on natural resource rents, 1970-99. Conflict Management and Peace Science 24(3), 201-218.

DJankov, S. \& Reynal-Querol, M. (2007). The colonial origins of civil war. SSRN Working Paper. http://papers.ssrn.com/sol3/papers.cfm?abstract_id=1003337.

Fearon, J. D. \& Laitin, D. D. (2003). Ethnicity, insurgency, and civil war. American Political Science Review 97(1), 75-90.

Fincher, C. L., Thornhill, R., Murray, D. R. \& Schaller, S. (2008). Pathogen prevalence predicts human cross-cultural variability in individualism/collectivism. Proceedings of the Royal Society B: Biological Sciences 275, 1279-1285.

Gallup, J. L., Sachs, J. D. \& Mellinger, A. D. (1999). Geography and economic development. International Regional Science Review 22(2), 179-232.

Ghobarah, H. A., Huth, P. \& Russett, B. (2003). Civil wars kill and main people - long after the shooting stops. American Political Science Review 97(2), 189-202.

Gizelis, T. I. (2009). Wealth alone does not buy health: Political capacity, democracy, and the spread of AIDS. Political Geography 28(2), 121-131.

Gleditsch, N. P., Wallensteen, P., Eriksson, M., Sollenderg, M. \& Strand, H. (2002). Armed conflict 1946-2001: A new dataset. Fournal of Peace Research 39(5), 615-37.
Hegre, H. \& Sambanis, N. (2006). Sensitivity analysis of the empirical literature on civil war onset. Fournal of Conflict Resolution 50(6), 937-961.

Lacina, B. A. (2006). Explaining the severity of civil war. Fournal of Conflict Resolution 50(2), 276-289

Lake, D. A. \& Baum, M. A. (2001). The invisible hand of democracy: Political control and the provision of public services. Comparative Political Studies 34(6), 587-621.

Letendre, K., Fincher, C. L. \& Thornhill, R. (2010). Does infectious disease cause global variation in the frequency of intrastate armed conflict and civil war? Biological Reviewes 85(3), 669-683.

LI, Q. \& WEN, M. (2005). The immediate and lingering effect of armed conflict on adult mortality: A time-series cross-sectional analysis. Fournal of Peace Research 42(4), $471-492$

Plümper, T. \& Neumayer, E. (2006). The unequal burden of war: The effect of armed conflict on the gender gap in life expectancy. International Organization 60(3), $723-754$.

Price-Smith, A. T. (2002). The Health of Nations: Infectious Disease, Environmental Change, and Their Effects on National Security and Development. Cambridge: MIT Press.

Pritchett, L. \& Summers, L. H. (1996). Wealthier is healthier. The fournal of Human Resources 31(4), 841-868.

Raoult, D., Ndihokubwayo, J. B., Tissot-Dupont, H., Roux, V., Faugere, B., Abegbinni, R. \& Birtles, R. J. (1998). Outbreak of epidemic typhus associated with trench fever in Burundi. Lancet 352(9125), 353-358.

Ross, M. L. (2004). What do we know about natural resources and civil war? fournal of Peace Research 41(3), 337-356.

Sachs, J. D., Mellinger, A. D. \& Gallup, J. L. (2001). The geography of poverty and wealth. Scientific American 284(3), 71-74.

Strand, H. (2006). Onset of armed conflict: A new list for the period 1946-2004, with applications. Typescript.

TognotTi, E. (2009). Program to eradicate malaria in Sardinia, 1946-1950. Emerging Infectious Diseases 15(9), 1460-1466.

Turchin, P. \& Nefedov, S. A. (2009). Secular cycles. Princeton, NJ: Princeton University Press.

(Received 20 September 2010; revised 7 June 2011; accepted 8 June 2011; published online 26 June 2011) 